\title{
The Factors influence the Students' Learning Outcome in Translation Subject by Using Android
}

\author{
Refika Andriani ${ }^{1}$, Destina Kasriyati ${ }^{2}$ \\ 1email: andriarefi@gmail.com \\ Universitas Lancang Kuning \\ 2 email: destinakasriyati@gmail.com \\ Universitas Lancang Kuning
}

\begin{abstract}
This research aimed at describing the factors influence the students' learning outcome in Translation Subject by using Android. This research conducted at the fourth semester of English Department of Education and Teachers Training Faculty of Universitas Lancang Kuning. The sample of this research is $30 \%$ of the total number of the population, they are about 7 students. The method of this research is descriptive analysis. Before getting the data by interviewing the students and observation during teaching and learning process of Translation Subject by using android, they had got a test of translating an English text into bahasa Indonesia. Finally, it is found that there are three factors influence the students learning outcome in translation subject by using android. They are motivated media, learning atmosphere, and easy access.
\end{abstract}

Keywords: Learning Outcome, translation, interactive, android 


\section{INTRODUCTION}

Nowadays, the use of technology cannot be separated from the human life. It is not only for communication, entertainment, and business purposes, but also for educational purposes. We can see that today the developing of learning media has a big part in improving the effectiveness of learning activity. As the example is the use of android smartphone as learning media to encourage the students' interest in the learning process. This situation is supported by a study conducted by UNICEF Indonesia in 2013. It stated that the ownership of android smartphone has increased doubly in 2012 and 2013. In other words, smartphone plays a great role of internet usage $52 \%$ beats the computer or laptop usage.

Smartphone is well known as a gadget because it is practice to use. With its open source android, android has cheaper price than computer or laptop. Android smartphone is a phone which has computer ability, wide screen, and able to run the general application. Baker (2010) says that smartphone is a phone which unites the future specs; it is an ability form wireless mobile device (WMD) which functions like a computer with features such as personal digital assistant (PDA), internet access, email, and Global Positioning System (GPS). Smartphone also has functions like camera, video, mp3 players. In conclusion, android smartphone is categorized as minicomputer with various features and easy to use everywhere and anywhere.

In the other words, android smartphone is a tool that can be used as a learning media for improving the students' motivation in learning. Even though it is made for communication, it can be used for other purposes based on its own facilities. Finally, the learning obstacles in the classroom can be solved. So, the learning activities can be increased significantly. Based on the above phenomenon, the researcher was interested to identify the factors why android can be used as one of the learning media to improve the students' learning outcome especially in the fourth semester students of English Education Department of Education and Teachers Training Faculty of Universitas Lancang Kuning Academic Year 2017/2018.

\section{A. Learning Media}

The use of learning media is a way to make the students get the concrete object about the concept that they have to understand. One of the media that can help the students to improve the learning activity is interactive multimedia. According to Edgar Dale (1969), the use of media is very important in education to gain the optimal outcome based on the goal. 
Abdullah (2012) stated that the quality of interaction between students and learning sources will influence the learning outcomes. So that, there is a big different between students who have higher intensity and for them who have the lower one in the use of learning sources in gaining their learning outcomes.

Anderson in Sadiman (1991) said that teacher needs to focus on the instructional media, characteristics and the ability of the media that can be used in learning process. The use of this media aims at creating the learning process effectively. Goes along with it, Sudjana and Rivai (2011) said that the advantages of learning media are motivating the students, supporting the learning material, learning method becomes various and enjoyable, and make the students easy to involve their self in the learning activity.

Interactive media is a media with software and hardware that can be used as the intermediary tool to deliver the learning material from the learning source into learning process with the learning method that can give the response from the user.

Learning process by using android interactive media as elearning is a multimedia learning. Communication and interaction will take place more effective between practitioner and students. Practitioner delivers learning material and students give responses to the learning material given. Gagne
(1988) said that practitioner is not only delivering the material, but also take the feedback from the students and reinforce to the students' learning outcome.

In this research, android as the interactive media is a social media application namely Edmodo. Edmodo is a kind of social media made for learning activity. In another word, it is made for learning purposes, because every teacher can make his/her own classroom with some features supported such as chatting, giving comment, and posting and also downloading contents. The use of this media is expected can be able to improve the students learning outcome.

\section{METHOD}

The method of the research is descriptive qualitative in which the data were collected by doing observation during learning process of translation subject by using android and interviewing the students of fourth semester of English Education Department of Education and Teachers Training Faculty of Universitas Lancang Kuning in Academic Year 2017/2018. The research was conducted from March to June 2018. The data collected was analysed, classified, and interpreted to identify the factors influence the students learning outcome by using android. 


\section{FINDINGS AND DISCUSSION}

This research used a structured interview as the primer instrument and observation as the secondary instrument. These instruments were used to find out the data need about the factors influence the students' learning outcome in translation subject.

After conducting the research and analysing the data, it is found that there were three factors influence the students' learning outcome by using android. They were motivated media, learning atmosphere, and easy access.

Based on the observation during learning process of translation subject by using android, the researcher noted that the learning process was running so well and effective. It can be seen from the result of observation in which the researcher wrote that almost of the students interested in giving responses to some questions and situations given by the lecturer. They were being more active in involving their selves in every case given.

Besides that, all of students said that they loved to learn by using android because it was more interesting. They could involve their selves with no worry about some friends will mock of their mistaken and they could give some comments with no shy. It can be concluded that android has a great motivation to the students' willingness in learning process.
Learning atmosphere was also the factor influence the students' learning outcome in translation subject by using android. From the observation, it was found that students feel enjoy and no stress during the learning process. They came to the class on time, and they were only two or three students go out during the class with the logical reason such as having to go to the rest room and having very important call.

In this point, students said that they enjoy the class because they had no direct pressure to give the responses to the case given. It made them easy to think first before delivering the comments or ideas deal with the material given by the lecturer. So, they could get some references and time to discuss to avoid mistaken ideas.

The last factor is easy access. It means that the students easy to get some information and to share ideas and comments based on the material given. It caused by all of students' androids had full access to the references needed. Based on the observation, the researcher shows that students more focus to get information from their android without any interference from other friends.

Based on the interview, almost of students said that that the use android made them easy and fast to get information needed. So, they did not waste the time just for asking the 
other friends about unclear material. Besides that, if there is no internet access of their android, they still had hot spot from the campus.

The result of this research said that the use of android as learning media in learning process was very effective. The factors influence the students' learning outcomes were about the sophisticated media itself. Android smartphone is not only for communication purposes but also can be for educational purposes.

\section{CONCLUSION}

Based on the finding, it can be concluded that android smartphone can be used by the practitioners to help them to support their teaching activities. It made them easy to encourage the students to follow the class actively and effectively. For the students, it can be seen that students felt interest in learning process, they also enjoy the class because the atmosphere was very pleasure, and the access of getting information and sharing ideas was easy to get.

\section{REFERENCES}

Abdullah, Ramli. 2012. Pembelajaran Berbasis Pemanfaatan Sumber Belajar. Jurnal Ilmiah DIDAKTIKA. VOL. XII NO. 2, 216-231

$\begin{array}{cr}\text { Andriani, Refika. } & \text { "Improving } \\ \text { Students' } & \text { Vocabulary } \\ \text { Mastery using } & \text { Interactive } \\ \text { Multimedia." } & \text { ELT-Lectura } \\ \text { 3.1 (2016). } & \end{array}$

Arsyad, Azhar. 2002. Media Pembelajaran. Jakarta: PT. Raja Grafindo Persada.

Baker, Mona. 2006. In Other Words. London \& New York: Rouledge, Taylor and Francis Group.

Bassnett, Susan dan Andre Lefevere (Eds.). 2002. Translation, History and Culture. USA: Cassell.

Dale, E. 1969. Audio Visual Methods in Teaching. (Third Edition) New York: The Dryden Press.

Gagne, R.M. and M.P. Driscoll. 1988. Essentials of Learning for Instruction. New York: Prentice Hall, Inc.

Hatim, Basil and Jeremy Munday. 2004. Translation An advanced resource book. London \& New York: Rouledge, Taylor and Francis Group.

Keller, J. M. 1987. Development and Use of The ARCS Model of Motivational Design, Journal of Instructional Development, 10(3), 2-10. (http://www.arcsmodel.com/ , diakses 29 Juni 2012).

Kemmis, S dan R. Mc Taggart. 1998. The Action Research Planner. Victoria: Deakin University.

Larson, $\quad$ Mildred L. 1988. Penerjemahan Berdasarkan 
Makna: Pedoman untuk Pemadanan Antarbahasa (Diterjemahkan oleh Kencanawati Taniran dari Meaning-based Translation: A Guide to Cross Language Equivalence). Jakarta: Penerbit Arcan.

Molina dan Albir. 2002. Teknik Menerjemah.

http://ihsania.blog.uns.ac.id/ teknik-penerjemahan$\underline{\text { menurut-molina-dan-albir/ }}$

Nababan, M. Rudolf. 2003. Teori Menerjemah Bahasa Inggris. Pustaka Pelajar: Yogyakarta.

Newmark, Peter. 1988. A textbook of Translation. London: Prentice Hall.

Nida, Eugene A. dan C.H. Taber. 1976. Language Translation and Translation. California: Stanford University.

Refika, Andriani, and Wahyuni Devi. "Improving Students' Writing Skill in Narrative Text by Using Storybird." ELT-Lectura 5.1 (2018): 7885.

Silaban, Antri Lilin, and Refika Andriani. "Using Flyswatter Game to Improve Students' Vocabulary Mastery at Grade Eigth SMP Dwi Sejahtera
Pekanbaru." ELT-Lectura 4.2 (2017).

Syaifullah, Syaifullah, Refika Andriani, and Destina Kasriyati. "Analisis Figure of Speech dalam Terjemahan Puisi "My Mistress' Eyes are Nothing Like the Sun" oleh Mahasiswa Prodi Pendidikan Bahasa Inggris Fakultas Keguruan dan Ilmu Pendidikan Universitas Lancang Kuning." Lectura: Jurnal Pendidikan 9.1 (2018): 95-104.

Sadiman, dkk. 2010. Media Pendidikan "Pengertian, Pengembangan dan Pemanfaatannya". Jakarta: PT Raja Grafindo Persada.

Soekamto dan Winataputra. 1995. Teori Belajar dan ModelModel Pembelajaran. Jakarta: Departemen Pendidikan dan Kebudayaan Republik Indonesia.

Undang-Undang Republik Indonesia Nomor 20 Tahun 2003 Tentang Sistem Pendidikan Nasional, Jakarta: Departemen Pendidikan Nasional Republik Indonesia.

Winkel, 1996. Psikologi Pengajaran. Edisi Revisi, Jakarta: PT Gramedia Widya Sarana. 